University of Nebraska - Lincoln

DigitalCommons@University of Nebraska - Lincoln

Papers in Communication Studies

Communication Studies, Department of

6-2007

\title{
Debate as a Weapon of Mass Destruction
}

Eric English

University of Pittsburgh, ericedwardenglish@gmail.com

Stephen Llano

University of Pittsburgh

Gordon R. Mitchell

University of Pittsburgh

Catherine E. Morrison

University of Pittsburgh

John Rief

University of Pittsburgh

See next page for additional authors

Follow this and additional works at: https://digitalcommons.unl.edu/commstudiespapers

Part of the Communication Commons

English, Eric; Llano, Stephen; Mitchell, Gordon R.; Morrison, Catherine E.; Rief, John; and Woods, Carly, "Debate as a Weapon of Mass Destruction" (2007). Papers in Communication Studies. 32.

https://digitalcommons.unl.edu/commstudiespapers/32

This Article is brought to you for free and open access by the Communication Studies, Department of at DigitalCommons@University of Nebraska - Lincoln. It has been accepted for inclusion in Papers in Communication Studies by an authorized administrator of DigitalCommons@University of Nebraska - Lincoln. 


\section{Authors}

Eric English, Stephen Llano, Gordon R. Mitchell, Catherine E. Morrison, John Rief, and Carly Woods 


\title{
Debate as a Weapon of Mass Destruction
}

\author{
Eric English, Stephen Llano, Gordon R. Mitchell, \\ Catherine E. Morrison, John Rief \& Carly Woods
}

Corresponding author - Eric English, Department of Communication, University of Pittsburgh, 1117 Cathedral of Learning, Pittsburgh, PA 15260, USA; email ericedwardenglish@gmail.com

$\mathrm{I}_{\mathrm{t}}^{\mathrm{t}}$ is 2002, nearly a year after 9/11. A New York City high school receives a package emblazoned with the words "WEAPONS OF MASS DESTRUCTION." The police are summoned, the building evacuated, and the sender of the package frantically called. Inside the package, investigators find ... evidence.

Debate evidence. The school had received a package of documents for New York Urban Debate League students, who were preparing to debate the national interscholastic debate topic for that year, "Resolved: That the United States Federal Government should establish a foreign policy significantly limiting the use of weapons of mass destruction." Was the package dangerous? It did not contain a bomb. Yet suspicions about the box's contents and those involved in the transaction lingered.

This episode is a representative anecdote for the "global war on terror," where lines separating friend and foe are persistently blurred, forcing combatants and bystanders alike to perform their allegiances in word and deed. A hyper-politicization of speech contours contemporary public discourse, policing the line between the sayable and unsayable and sorting people into neat categories such as "with us or with the terrorists." We have seen this before. In another indefinite war of ideology, debate was similarly suspected of being a weapon of mass destruction capable of jeopardizing homeland security. As the Soviets tested their atom bomb in August of 1949, Americans worried that nuclear secrets had been passed to the USSR from communist sympathizers within the US government. Fear of being "sold out" by "fifth columnists" at home increased penalties for dissent, placing blame at the feet of anyone who dared undermine American security by sowing division.

This essay grew out of collaborative research by the Schenley Park Debate Authors Working Group (DAWG), a consortium of public argument scholars at University of Pittsburgh. Founded in 2005, the Schenley Park DAWG strives to generate rigorous scholarship addressing the role of argumentation and debate in society. First author Eric English led work on this DAWG essay, while the co-authors each contributed substantially in areas of conceptual design, research, and writing. Gordon Mitchell is Associate Professor of Communication at the University of Pittsburgh. Each of the other co-authors is a graduate student in the Department of Communication at the University of Pittsburgh. All are past or present Pitt debate coaches. 
Within this context, the Speech Association of America (precursor to today's National Communication Association) invited thousands of college students to debate the relative merits of an American diplomatic recognition of the People's Republic of China in 1954. Anxiety spread about the ability of students to engage the topic safely; every team would be asked to defend both sides of this resolution, a common tournament procedure known as "switch-sides" debate. Some argued that the practice would indoctrinate America's youth, while giving aid and comfort to the enemy. "For even a small segment of American college students to rise at this time to the defense of this Communist Government would be sweet music to the ears of Moscow and Peiping," wrote debate instructor Charles R. Koch, as he pulled his own team from competition in protest. $^{1}$

Given the switch-side norm of academic debate and the highly controversial nature of the resolution, "the US Military Academy, the US Naval Academy and, subsequently, all of the teacher colleges in the state of Nebraska refused to affirm the resolution."2 A predominant military concern was that, "a pro-recognition stand by men wearing the country's uniforms would lead to misunderstanding on the part of our friends abroad and to distortion by our enemies." ${ }^{3}$ Karl Wallace, then president of the scholarly organization that now sponsors this journal, was pressured heavily to change the China topic. ${ }^{4}$ His firm and principled resistance is documented in an official statement emphasizing that "inherent in the controversy" over the 1954 debate resolution "is an alarming distrust of the processes essential to a free society." 5 The fierce controversy even drew in journalist Edward R. Murrow, who backed Wallace's position in an edition of the See it Now television program seen by millions. Some complained that "discussions of this topic were channeled to bring out criticism" of McCarthy himself. ${ }^{6}$ The timing of the red-baiting senator's political implosion, which followed shortly after the Wallace and Murrow statements, suggests that the great 1954 "debate about debate" indeed may have helped rein in McCarthyism run amok.

But this outcome seems paradoxical. How can an activity that gives voice to extreme views moderate extremism? Speech professor Jeffrey Auer's 1954 statement may hold the key: "A person, because he supports the recognition of Communist China, isn't a communist, any more than because he supports the recognition of Communist China, he is a Chinaman."7 Just as walking a mile in unfamiliar shoes lends perspective, switch-side debating increases appreciation of contrary opinions as the debater "tries on" an unfamiliar idea rather than relying on simplification, reduction, or rejection. In fact, debating both sides encourages participants to dismantle absolutist "us versus them" dichotomies. This may explain why those invested in the stability of such polar categories find debate so threatening.

The shadow of 1954 suggests that academic debating in a post-9/11 political environment could be hazardous. The New York City high school debaters described above certainly had cause for alarm. But police confiscation of their speaking briefs was more accident than trend. A closer look at contemporary academic debate reveals features that make it seem markedly less subversive than its 1954 version. 
This year's intercollegiate policy debate topic calls on affirmative teams to overrule one of four Supreme Court decisions, including Ex parte Quirin, the precedent frequently invoked to justify homeland security policies such as military tribunals for Guantanamo detainees. ${ }^{8}$ In arguing to overturn Quirin, debaters employ a variety of approaches. Most teams contend that the Supreme Court's 2006 Hamdan v. Rumsfeld decision, while helpful, does not go far enough in limiting the scope of military commissions. In this view, leaving Quirin on the books enables a troubling expansion of presidential power, with the potential to destroy transatlantic relations and abrogate US obligations to the Geneva Convention. Others use testimony, narratives, and poetry from ex-detainees like Afghan poet Abdul Rahim Muslim Dost and British memoirist Moazzam Begg to highlight the human rights abuses and torture allegations at Guantanamo Bay. If this sounds radical, consider that such cases have been met with objections from negative opponents that piecemeal reforms are cosmetic drops in the bucket, with durable systemic change only likely to come from more revolutionary measures such as presidential impeachment, anarchy, or world government.

Today's intercollegiate debaters find themselves in a political landscape resembling 1954 in several respects. Once again, we find prominent political figures attempting to define the contours of public debate by portraying critics as unpatriotic. Vice President Cheney says that "disagreement, argument and debate are the essentials of democracy," yet stipulates that charges of pre-war intelligence manipulation are "dishonest and reprehensible." 9 Such contortions are typical examples of how skillfully McCarthy's ideological descendants attack the process of democracy in the name of democracy. The conservative punditry also does its part. While Ann Coulter accuses Iraq war critics of treason, David Horowitz revives fears of a liberal (and therefore "dangerous") academic elite poisoning the minds of America's young adults. Despite these and countless other examples of McCarthyist tendencies, many directed specifically at academia, there has been no outcry about college students "taking the side of terrorists" in competitive debate tournaments. Why?

One answer is that intercollegiate policy debate has become remarkably isolated and esoteric. Competitive pressures have molded the activity into a highly technical art form, where students argue in jargon at breakneck speeds that regularly top 300 words per minute. Because so few people can participate in these debates, virtually no one observes them; untrained spectators are often baffled. The coin has two sides, for the isolation of this form of debate both protects it from criticism and prevents it from having a broader social effect. The result is an odd oasis of intellectual ferment bearing resemblance to the carefully demarcated "free speech zones" that dot the periphery of today's controversial public events.

Second, while the pedagogical benefits of switch-side debating for participants are compelling, ${ }^{10}$ some worry that the technique may perversely and unwittingly serve the ends of an aggressively militaristic foreign policy. In the context of the 1954 controversy, Ronald Walter Greene and Darrin Hicks suggest that the articulation of the debate community as a zone of dissent against McCarthyist tendencies developed into a 
larger and somewhat uncritical affirmation of switch-side debate as a "technology" of liberal participatory democracy. This technology is part and parcel of the post-McCarthy ethical citizen, prepared to discuss issues from multiple viewpoints. The problem for Greene and Hicks is that this notion of citizenship becomes tied to a normative conception of American democracy that justifies imperialism. They write, "The production and management of this field of governance allows liberalism to trade in cultural technologies in the global cosmopolitan marketplace at the same time as it creates a field of intervention to transform and change the world one subject (regime) at a time." ${ }^{\prime 11}$ Here, Greene and Hicks argue that this new conception of liberal governance, which epitomizes the ethical citizen as an individual trained in the switch-side technique, serves as a normative tool for judging other polities and justifying forcible regime change. One need look only to the Bush administration's framing of war as an instrument of democracy promotion to grasp how the switch-side technique can be appropriated as a justification for violence.

It is our position, however, that rather than acting as a cultural technology expanding American exceptionalism, switch-side debating originates from a civic attitude that serves as a bulwark against fundamentalism of all stripes. Several prominent voices reshaping the national dialogue on homeland security have come from the academic debate community and draw on its animating spirit of critical inquiry. For example, Georgetown University law professor Neal Katyal served as lead plaintiff 's counsel in Hamdan, which challenged post-9/11 enemy combat definitions. ${ }^{12}$ The foundation for Katyal's winning argument in Hamdan was laid some four years before, when he collaborated with former intercollegiate debate champion Laurence Tribe on an influential Yale Law Journal addressing a similar topic. ${ }^{13}$

Tribe won the National Debate Tournament in 1961 while competing as an undergraduate debater for Harvard University. Thirty years later, Katyal represented Dartmouth College at the same tournament and finished third. The imprint of this debate training is evident in Tribe and Katyal's contemporary public interventions, which are characterized by meticulous research, sound argumentation, and a staunch commitment to democratic principles. Katyal's reflection on his early days of debating at Loyola High School in Chicago's North Shore provides a vivid illustration. "I came in as a shy freshman with dreams of going to medical school. Then Loyola's debate team opened my eyes to a different world: one of argumentation and policy." As Katyal recounts, "the most important preparation for my career came from my experiences as a member of Loyola's debate team."14

The success of former debaters like Katyal, Tribe, and others in challenging the dominant dialogue on homeland security points to the efficacy of academic debate as a training ground for future advocates of progressive change. Moreover, a robust understanding of the switch-side technique and the classical liberalism which underpins it would help prevent misappropriation of the technique to bolster suspect homeland security policies. For buried within an inner-city debater's files is a secret threat to absolutism: the refusal to be classified as "with us or against us," the embracing of intellectual experimentation in an age of orthodoxy, and reflexivity in the face of fundamentalism. But by now, 
the irony of our story should be apparent ${ }^{\star}$ the more effectively academic debating practice can be focused toward these ends, the greater the proclivity of McCarthy's ideological heirs to brand the activity as a "weapon of mass destruction."

\section{Notes}

[1] Charles R. Koch, Letter to the Committee on Intercollegiate Debate and Discussion, 1 October 1954, Faculty papers, Karl R. Wallace, Series V. Communication Pedagogy, C. Miscellaneous Papers R_Z, Box 22, Group 40/11, Folder 49, Archives of the University of Massachusetts, Amherst. Hereafter cited as "Wallace papers."

[2] Ronald Walter Greene and Darrin Hicks, "Lost Convictions: Debating Both Sides and the Ethical Self-fashioning of Liberal Citizens," Cultural Studies 19 (2005): 103.

[3] James MacGregor Burns, “Debate Over Collegiate Debates,” New York Times Magazine, 5 December 1954, 12.

[4] See, for example, Herbert L. Cushing, Letter to Karl Wallace, 27 September 1954; Neal S. Gomon, Letter to Karl Wallace, 21 October 1954, Wallace papers, Folder 49.

[5] Karl R. Wallace, Winston L. Brembeck, Glenn L. Jones, T. Earle Johnson, Lawrence E. Norton, Robert G. Gunderson and Austin J. Freeley, Committee on International Discussion and Debate statement, 29 November 1954, Wallace papers, Folder 49.

[6] "Oppose Choice of Red China as Debate Topic," Chicago Daily Tribune, 14 October 1954, part 2, 9 .

[7] J. Jefferey Auer, interview with Lindley J. Stiles, "Should Debaters be Allowed to Discuss Controversial Questions?" Stenographic transcription from "A Letter from the Dean," weekly radio program broadcast by nearly twenty Virginia stations. Wallace papers, Folder 49.

[8] George Lardner Jr., "Legal Scholars Criticize Wording of Bush Order: Accused Can Be Detained Indefinitely," Washington Post , 3 December 2001, A10.

[9] BBC News, "Cheney Says Iraq Debate Essential," 21 November 2006, http://news.bbc. co.uk/2/hi/middle east/4457818.stm

[10] See Star Muir, "A Defense of the Ethics of Contemporary Debate," Philosophy and Rhetoric , 26 (1993): 277_95.

[11] Greene and Hicks, "Lost Convictions," 121.

[12] Hamdan v. Rumsfeld, 548 US (2006).

[13] Neal Kumar Katyal and Laurence H. Tribe, “Waging War, Deciding Guilt: Trying the Constitutionality of the Military Tribunals," Yale Law Journal 111 (2002): 101_52.

[14] Neal Katyal, quoted in “Alumni Making a Difference," Loyola Academy Focus (Fall 2006). 